\title{
Hydraulic Geometry, Hydraulics and Sediment Properties of Forest Brooks after Extensive Erosion from Upland Peatland Drainage
}

\author{
Hannu Marttila, Simo Tammela, Bjørn Kløve \\ Water Resources and Environmental Engineering Laboratory, University of Oulu, Oulu, Finland \\ Email: hannu.marttila@oulu.fi
}

Received April $5^{\text {th }}, 2012$; revised May 27 ${ }^{\text {th }}, 2012$; accepted June $15^{\text {th }}, 2012$

\begin{abstract}
Peatland drainage can affect headwater systems, causing changes in bed substrate composition and hydraulic geometry in small brooks. We studied hydraulic geometry and sediment properties in 14 boreal forest brook reaches (width $<2$ $\mathrm{m}$ ), characterised by well-vegetated banks, high sinuosity and low width-to-depth ratio, in north-east Finland. The aims were to obtain information from channel geometry and to study brook response to extensive sediment load from land use. The results indicate that bed sediment in brooks is almost continuously mobile, which negatively reflect to ecological status of the brooks. These headwater meandering parts have limited sediment transport capacity and require a long period to recover from artificially increased sediment input from peat drainage. However, different reaches can be prioritised for restoration according to the characteristics of silted bed sediment or sediment origins. Brook width appeared to have large natural variation, causing great local velocity variations. This needs to be taken into consideration when restoring straightened reaches in small headwater areas, e.g., width in restored reaches cannot be uniform but should include variations.
\end{abstract}

Keywords: Forest Brook; Headwater; Hydraulic Geometry; Hydraulics; Peatland Drainage; Sediment

\section{Introduction}

Assessing the hydraulic geometry and sediment properties of boreal forest brooks is important for improving management and restoration of these fluvial systems. In general, hydraulic and sediment conditions in streams support a number of physical, chemical and biological processes, resulting in suitable habitats for flora and fauna. Headwater brooks occupy an extensive area of landscape and differ from larger stream systems in a great many of ways (e.g. channel dimensions, sediment transport, fish abundance and the disturbance regime associated with low flows). These different physical conditions shape and support a high level of biological diversity that differs from larger river systems. Furthermore, small headwater streams are crucial in larger river catchments as collectors of surface waters and receivers of loads from the catchment area. About $80 \%-90 \%$ of the water flows through the first and second order streams [1] and therefore the state of small streams obviously reflects that of downstream waterways.

Changes in land use and sediment delivery can dramatically alter hydraulic, hyporheic and bed substrate conditions, especially in small brooks. In Finland, peat- land-dominated catchments and headwater brooks have been strongly altered due to intensive peatland drainage for forestry. In some areas the problems have multiplied due to lack of sufficient water protection. Drained peatlands are widespread features of managed forest lands in Finland, comprising $53 \%$ of the 8.9 million ha of Finnish peatlands [2]. High rates of sediment production from peatland drainage networks occur during the first year following excavation operations [3], but diminish over time [4]. Sediment production from drainage operations often exceeds natural sediment production in headwater brooks, which is small in these environments [5]. There is limited information of natural sediment production in these headwaters but it has been assumed to be very small. Most natural forest streams in the boreal zone in Finland and other countries of Fennoscandia are affected by forestry operations. Excessive sediment alters brook habitat and bed substrate conditions, for example by silting up pools, which are essential habitat elements for fish (e.g. Salmo trutta), providing cover, a winter habitat and a flood refuge. Although multiple variables control the suitability of the brook channel as a habitat, bed substrate plays dominant role. Substrate mobility and characteristics such as size, sorting, and composition (e.g. natural or 
anthropogenic, inorganic or organic, etc.), are important for habitat quality and availability [6]. Sediment mobility, composition and impacts e.g. on hyporheic structure have been examined in high gradient stream [7-9] in lowland streams [10] and headwater streams over 3rd order [11]. Regardless of extensive amount of sediment studies, sedimentation and substrate composition have not been studied in small 1st and 2nd order forest brooks. Further, quantification of dominant discharge and sediment transport thresholds in these systems has not been undertaken.

In addition to bed substrate conditions, hydraulic geometry plays important role in stream habitat quality. Locally, in north-east Finland, many small brooks have been dredged and straightened to improve forest drainage, resulting in loss of natural hydraulic geometry and habitat conditions. Dredging has caused increased sedimentation on brook bottom and loss of pool-riffle morphology. Constantly moving sand on brook bottom prevents vegetation growth and therefore reduces habitat. Generally, the equilibrium stream channel has a geometry that allows it to carry water and sediment transported from the catchment area. At the same time, the channel is built and maintained by the flows and sediment delivered to it. A particularly important characteristic is bankfull stage, the point at which the channel and floodplain become connected. This determines the discharge at which there is a change to overbank flow and sediment trapping in floodplains. Channel bankfull geometry can be described in terms of width $(W)$, depth $(D)$, velocity $(w)$ and, using the relationship with discharge $(Q)$, it commonly takes the form of simple power law relations [12]. During recent decades there has been notable progress on documenting hydraulic geometry relationships in streams. However, research to date suggests that there is considerable variability in hydraulic geometry both within and between stream systems [13]. Thus, the relationships developed in one region are rarely transferred to other regions. Furthermore, site-specific factors, including bank stability, bed composition and channel shape, affect hydraulic geometry in stream networks [14]. This demands local studies to determinate local variables and conditions.

There has been little progress in explaining variations in hydraulic geometry, substrate and sedimentation conditions in small headwater brooks after intensive land use and this remains one of the central problems for brook restoration. In Finland, there is currently a clear need to restore damaged first and second order brooks and catchments. For selection of the most appropriate methods, locations and to maximise the benefits at catchment scale, more information is needed from the channel geometry and sediment processes. As in north-east Finland, the number of degraded brooks is large, so restoration activities need to target the most suitable areas which benefits most from the restoration activities.

The objectives and outline of this study were 1) to increase understanding of the relationships between channel geometry and flow in these small fluvial systems and 2) to examine bed substrate mobility, frequency and threshold, and floodplain sedimentation in a low gradient brooks which has suffered extensive sediment load from upstream land use. This information is needed for restoration of straightened brook reaches in the region and to classify restoration target areas from substrate mobility point of view. e.g. If reach bed composition can be naturally restored, it does not need restoration actions.

\section{Methods}

\subsection{Site Descriptions}

The main study area, Vantunlamminoja forest brook $\left(65^{\circ} 77^{\prime} 14^{\prime \prime} \mathrm{N}, 28^{\circ} 34^{\prime} 89^{\prime \prime} \mathrm{E}\right)$, is located in Taivalkoski, Northern Finland (Figure 1). Four reaches of this brook were studied. In addition, 10 headwater brooks (first or second order channels) under peatland forestry land use in Northern Ostrobothnia were sampled (Figure 1, Table 1). Drainage operations in all study reaches have resulted in major erosion in the drainage network. As a result, transported and deposited sediment has filled the channel bed in many reaches (Figure 2). These brook systems were among those inventoried in 2002 [15] and were classified as important restoration areas since they are natural brook trout habitats. The study focused on meandering parts of channels with low slope, suffering mostly from straightening operations and siltation from the peatland drainage. Since small brooks in the boreal forest are often characterized by missing channel features due to sub-surface flow, the following criteria for reach selection was used: 1) presence of a recognizable brook bed with meandering channel, 2) presence of upstream peatland drainage, 3) clear erosion location upstream and iv) bankfull width less than $3 \mathrm{~m}$.

The Northern Ostrobothnia sites lie within the River Iijoki basin and are within $60 \mathrm{~km}$ of the Vantunlamminoja site (Figure 1). All 14 study sites represent typical headwater brooks in the Bothnian bay area of northeastern Finland. The ground vegetation near the study channels is composed of Sphagnum moss, sedge (Carex $s p$.), and willow (Salix sp.) species. The tree stands at the site are mixed stands of Scots pine (Pinus sylvestris L.), Norway spruce (Picea abies Karst. (L.)), and downy birch (Betula pubescens Ehrh.). The soil in the study catchments is predominantly glacial till and peat. The peatland is sloping fen or valley fen, surrounded by glacial eskers and hills. The soil under the peat layer is predominantly fine lodgement till, contaiing some rocks. 

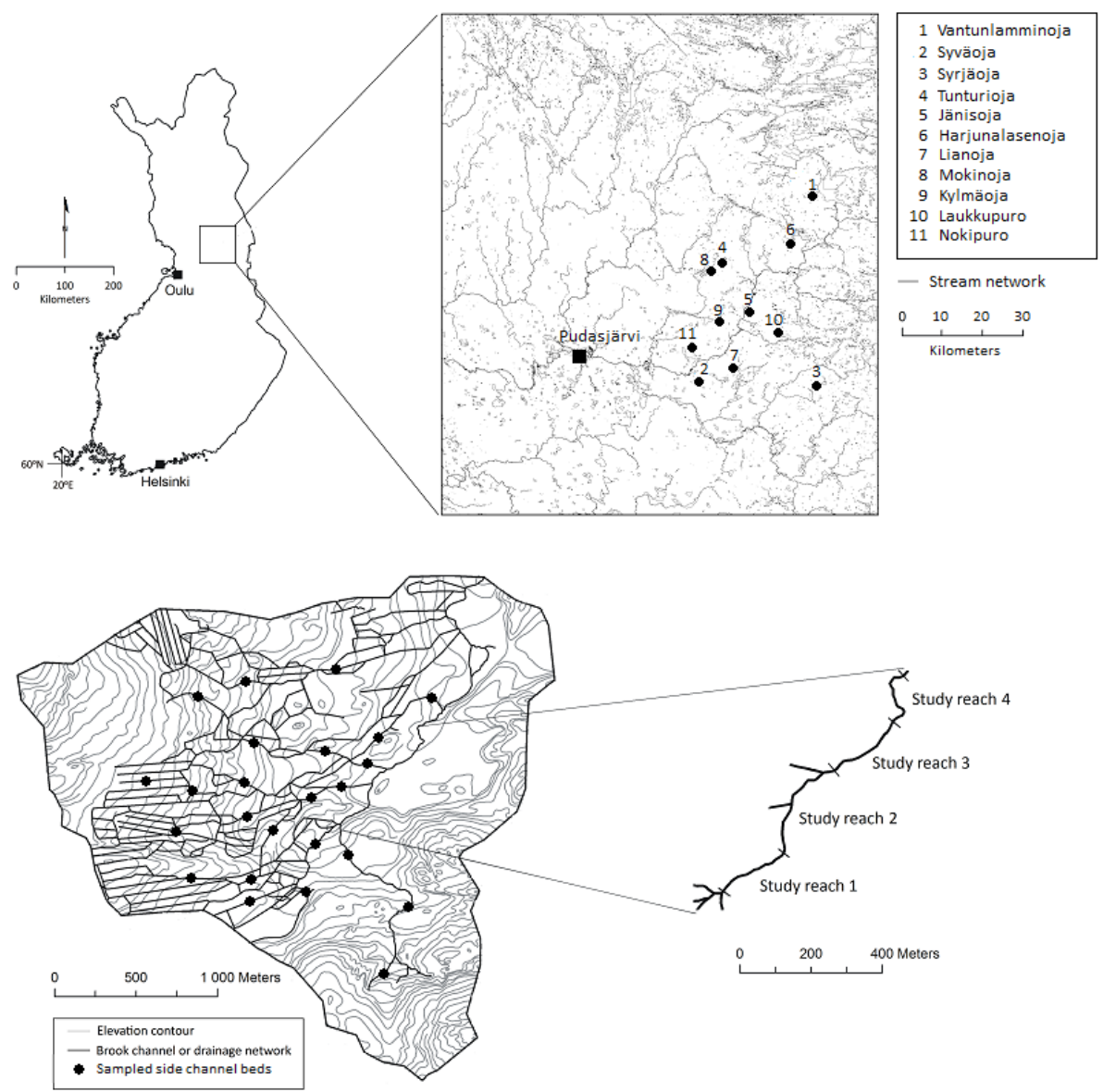

Figure 1. Locations of study sites (upper diagram) and the drainage area of Vantunlamminoja brook and locations of study reaches 1-4 (lower diagram).

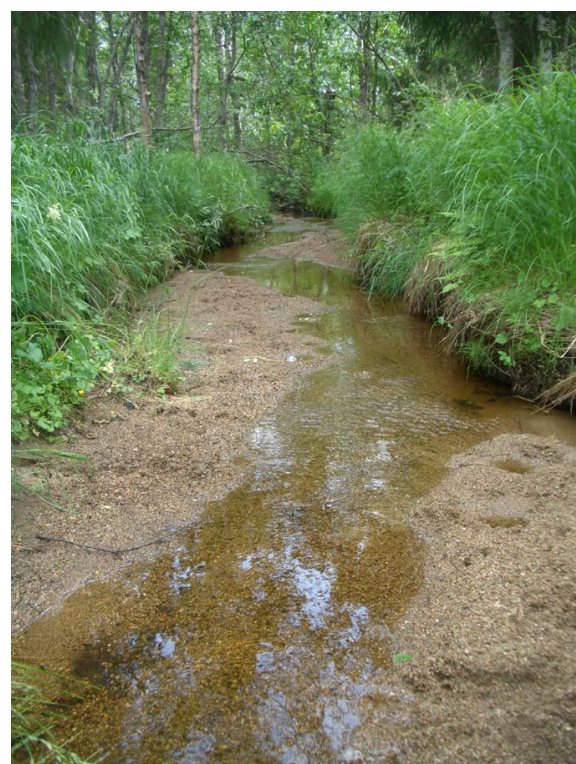

Figure 2. Silted brook channel reach at Vantunlamminoja. Coarse sand sediment eroded and transported from peatland forest drainage areas fills natural brook channels, reducing depth variations.
The long-term average annual precipitation is $695 \mathrm{~mm}$, mean annual air temperature is $0.2^{\circ} \mathrm{C}$ and annual evaporation is $230 \mathrm{~mm}$. During the study period the precipitation fluctuated markedly. The weather in 2006 was dry (total rainfall $569 \mathrm{~mm}$ ), 2007 had close to average long-term precipitation $(688 \mathrm{~mm})$ and 2008 was rather wet $(820 \mathrm{~mm})$.

Peatlands in the Vantunlamminoja catchment were drained for forestry in 1963 and maintenance work was carried out on the ditch network in 1993. The peatland forestry ditches are mainly located on the west side of the main Vantunlamminoja channel and consist of a linear channel network with an average drainage depth of $1 \mathrm{~m}$, width of $1-2 \mathrm{~m}$ and ditch spacing of $35-50 \mathrm{~m}$ (Figure 1). Many channels were dredged in the direction of the steepest slope during restoration (Figure 1), resulting in considerable erosion and transport of sediment to natural brook channels. Part of the drainage channel network is ephemeral, with water depth fluctuating from a few centimetres to $0.5 \mathrm{~m}$ in the main drainage channels. The drainage channels extend into the mineral soil at several locations in the drainage network. The elevation in the 
study area ranges from $230-350 \mathrm{~m}$, with a mean valley slope of $0.01 \mathrm{~m} \cdot \mathrm{m}^{-1}$ and total drainage area of $6.25 \mathrm{~km}$.

\subsection{Sampling}

Each of the 14 study sites was surveyed and described. The four different study reaches $(1-4)$ of the Vantunlamminoja brook were studied in detail along the whole reach (Figure 1). Stretches of reach were also measured and sampled within the 10 other study sites. The study reaches were geodetically surveyed and divided into several cross-sections in order to study geomorphological features (slope, sinuosity, bankfull, bed sediment, etc.). Channels were typically surveyed in cross-section at the base and top of each stream bank (bankfull), thalweg and 5 metres laterally from the channel to document the extent of the flood plain and establish the overall valley gradient and morphology. In total, $11-15$ points per cross-section were measured. These cross-sectional surveys were completed in every reach at one channel width intervals. Discharges during low-flow and bankfull stages were measured instantaneously using a current meter. In addition, the vegetation profile on brook banks was documented. Bankfull level was identified as the level corresponding to the top of the channel banks. Surveyed morphological characteristics (e.g. sinuosity and gradient) were deemed to be reliable, as the survey length for all reaches was at least 45 times the average width of the channel, which is sufficient to capture over four channel meanders [16]. The average values of different features in different reaches are presented in Table 1. The total lengths of the brooks studied here were taken from [15].

Bed and subsurface sediment materials were collected along the thalweg $(>500 \mathrm{~g})$. A $5.6 \mathrm{~cm}$ diameter plastic pipe was pushed into the streambed to a depth of $0.4 \mathrm{~m}$. When the pipe was removed, the top $0.05 \mathrm{~m}$ (bed) and $0.05-0.3 \mathrm{~m}$ (subsurface) of samples were taken to the laboratory. Where no armour layer was visible the sediment sample was taken with an Ekman sediment sampler [17]. The bed sediment samples were collected from several cross-sections (average 10 bed samples per reach) and average values per reach are summarised in Table 1. The depth of the sediment deposits was surveyed at every cross-section using a steel stick ( $1.5 \mathrm{~m}$ long). There were several sources of uncertainty associated with the sediment sampling procedure. Sediment sampling at Vantunlamminoja was conducted 16 times during the study period, but in 10 other study brooks the sampling operations were conducted only once. Furthermore, the results from all sediment samples collected were combined to give average sediment properties.

In addition, sediment samples ( $>500 \mathrm{~g})$ were collected from the banks and surrounding floodplains using a stainless steel trowel. Further, core sediment samples were taken from floodplains. These samples were collected soon after spring floods, in order to obtain material that characterised sediment transport by flood flow. The samples were collected from several cross-sections (average $10-15$ per reach) and average values per reach are listed in Table 1. In the catchment area, sediment samples were taken at erosion locations from where the silted and transported sediment was delivered to the study brook. In addition, at the Vantunlamminoja site sediment samples were collected from smaller side-channel beds $(\mathrm{n}=24)$ using the stainless steel trowel. At laboratory, each sediment sample was sieved using mesh screens and organic content determinate after incineration at $550^{\circ} \mathrm{C}$ for $2 \mathrm{~h}$.

Bed load during bankfull conditions at Vantunlamminoja was measured using a stream-side sampler [18], which allowed the energy of the stream to move bedload sediment up the collection ramp and into a hopper. With side-wings in sampler all brook bed load were collected into a hopper. The measurements were conducted during high flow events, as most of the bedload was expected to be transported during these events. During these events sampler were positioned to along the bed and allowed to collect bed load from 2 to 12 hours. A total of nine bedload measurements were performed in reach 3 . The particle size distribution of each bedload sample was determined by sieving. While most bedload was measured during high flow events, small bedload movements were also observed during lower flow events and affected the total annual bedload. In addition, bedload was not measured during winter conditions and the influence of this season on total budget is unknown.

Suspended sediment concentration was measured by depth-integrated sampler at monthly intervals in reach 3 . The sampler collected representative suspended sediment samples transported in the water column. The sediment concentrations in these samples were measured in the laboratory by filtering the sample through a glass microfibre filter $(\mathrm{GF} / \mathrm{C})$, pore size $1.2 \mu \mathrm{m}$ (SFS-EN 872: 2005). Continuous measurement of suspended solids was performed during 2006-2007 with a turbidity meter (YSI 600 ) using 15 -min measuring intervals. The turbidity value was calibrated against suspended sediment concentration using water samples.

At the Vantunlamminoja site, five cross-sections were selected for continuous discharge measurements, where water elevation was recorded at 15 -min intervals using water stage recorders (TruTrack, WT-HR). The discharge measurement period during 2006-2008 was from the onset of snowmelt (typically early May) until the end of October in each year. Regular flow measurements (monthly intervals) using a current meter were used to 


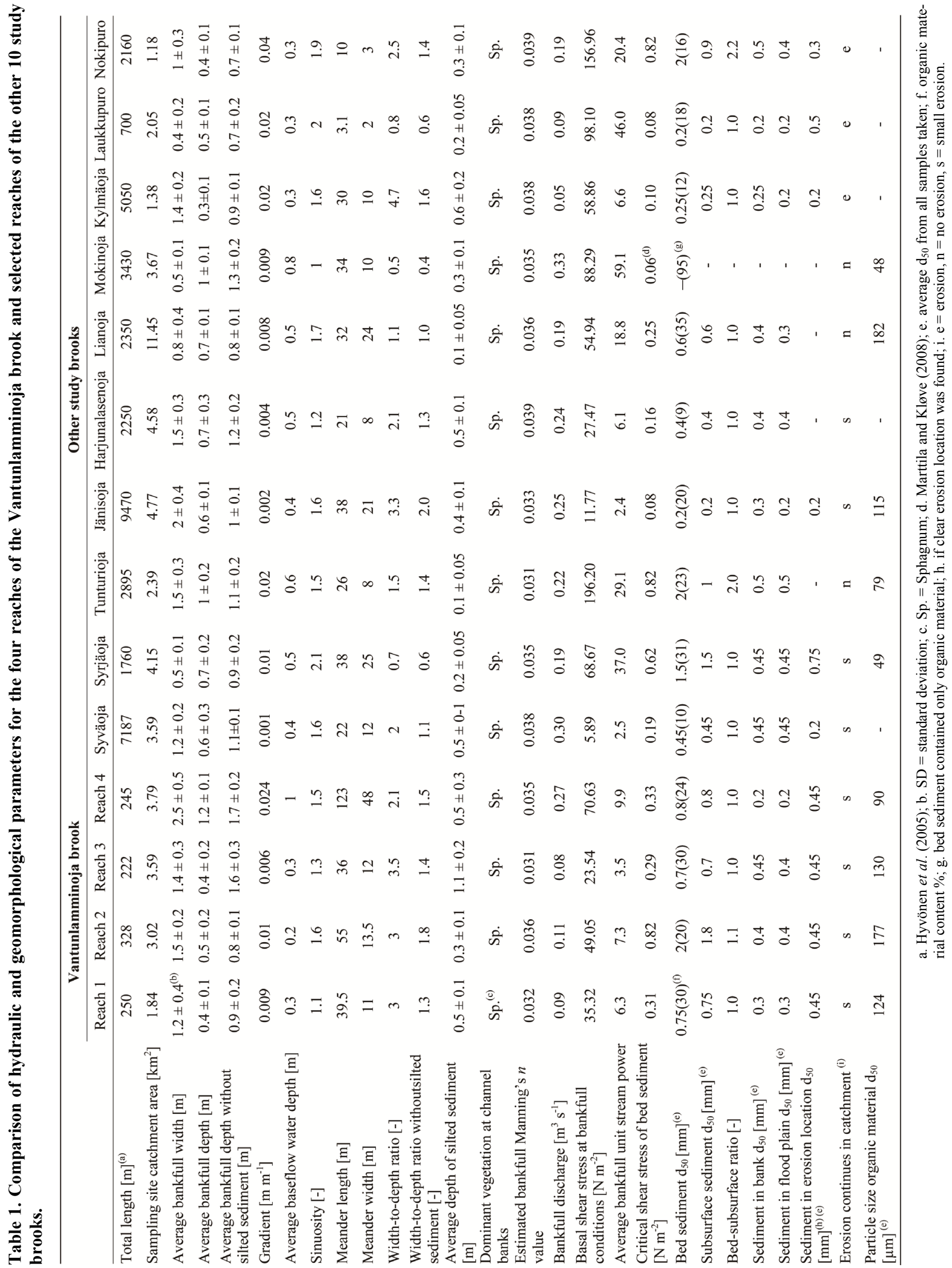


build rating curves specifying the relationship between stage and water discharge for each location. At the Vantunlamminoja site, the accuracy of bankfull conditions was determined from the stage readings. Bankfull discharge, bankfull shear stress, unit stream power and Manning's roughness values were determined from the stage-discharge curve for the location. For the other 10 study brooks these were calculated from bankfull discharge measurements. The values obtained are rough estimates for the study reaches, but reflect the natural variation in these environments. More information on the methods used can be found in the data analysis section.

\subsection{Data Analysis}

Bankfull discharge was calculated using Manning's equation for a trapezoidal open channel. Bankfull discharge calculations were based on the channel gradient, depth and width measurements from study reaches, and the Manning's roughness coefficient. The roughness coefficient was estimated using measured cross-section and discharge, and visual observation of vegetation in the field conditions, following the method proposed in previous studies $[19,20]$. It is important to note that the method included several uncertainties in the estimation, especially as the study areas were small brooks with heterogeneous conditions. The Manning's values were further tested against the measured discharge and these results were used to estimate the coefficient at bankfull conditions. Continuous discharge values were used at Vantunlamminoja and cross-sectional discharge values at the other 10 brooks. The results were combined to estimate the average Manning's $n$ value for total reach channel sections in different study areas.

Channel bankfull geometry was studied using the relationships between width $(W)$, depth $(D)$, velocity $(w)$ and discharge $(Q)$ obtained from simple power law relations [12]:

$$
\begin{gathered}
W=a Q^{B} \\
D=c Q^{f} \\
w=k Q^{m}
\end{gathered}
$$

Theoretical sediment mobility was calculated by comparing the ratio of basal shear stress $\left(\tau_{b}\right)$ to critical shear stress $\left(\tau_{c}\right)$ [21], [9]. This method provides a good approximation of reach-scale $\tau_{b}$ :

$$
\tau_{b}=\gamma_{w} h S_{c}
$$

where $h$ is water depth $(\mathrm{m}), \gamma_{w}$ is the specific weight of the fluid $\left(9800 \mathrm{~N} \cdot \mathrm{m}^{-3}\right)$, and $S_{c}$ is the channel slope $\left(\mathrm{m} \cdot \mathrm{m}^{-1}\right)$ (i.e. dimensionless). Basal shear stress can be expressed by the DuBoys equation [22].

Critical shear stress $\left(\tau_{c}\right)$ at which erosion begins was calculated as

$$
\tau_{c}=\theta\left(\gamma_{s}-\gamma_{w}\right) d
$$

where $\theta$ is Shields' parameter (dimensionless shear stress), $\gamma_{s}$ is the specific weight of sediment $(26,000 \mathrm{~N}$. $\mathrm{m}^{-3}$ used in this study), $\gamma_{w}$ is the specific weight of water, and $d$ is the particle diameter (m). In this study Shields' parameter of 0.044 was used, since it represents fully turbulent flow and can be used to indicate the threshold between motion and no motion $[23,24]$. When the ratio $\tau_{b} / \tau_{c}$ exceeds one, the theoretical basal stress exceeds the threshold for entraining the sediment [10]. For this study the $d_{50}$ was chosen as it indicates the threshold for potential mobility of $50 \%$ of the streambed sediment. Further, $d_{50}$ is biologically significant since biota diversity, density and production are linked to median particle size [25]. In cobble and gravel bed streams $d_{85}$ is often used to indicate bed movement, because larger particles inhibit the movement of the smaller particles by shielding the smaller particles from flow $[26,27]$. However, $d_{85}$ was not used in this since largest bed materials were smaller than coarse sand in study reaches. Calculated threshold values were used to determine whether the bed material in the study reaches was mobile during periods of bankfull flows and base flow.

Unit stream power (i.e. rate of energy dissipation against the bed and banks of a brook per channel width) during the bankfull stage [28] was calculated for the study sites using equation:

$$
\omega=\rho g Q S / b
$$

where $\omega$ unit stream power, $\rho$ is the density of water $\left(1000 \mathrm{~kg} \cdot \mathrm{m}^{-3}\right), \mathrm{g}$ is acceleration due to gravity $(9.81$ $\left.\mathrm{m} \cdot \mathrm{s}^{-2}\right), Q$ is discharge $\left(\mathrm{m}^{3} \cdot \mathrm{s}^{-1}\right), S$ is the channel slope, and $b$ is width of the channel (m).

\section{Results and Discussion}

\subsection{Geometry and Hydraulic Geometry}

Geometry and hydraulic geometry of studied brook reaches were diverse. In the 14 forest brook reaches studied, the average values for channel width, depth and gradient were $1.22 \mathrm{~m}, 0.64 \mathrm{~m}$ and $0.01 \mathrm{~m} \cdot \mathrm{m}^{-1}$, respectively (Table 1). The bankfull width ranged from 0.4 to $2.0 \mathrm{~m}$ and the bankfull depth from 0.3 to $1.2 \mathrm{~m}$ (Table 1). All reaches were degraded by siltation of transported sediment from peatland drainage areas, as drainage channels were excavated straight to the natural channel. In addition, the reaches had a low gradient (range from 0.001 to 0.04 ), resulting in settling and accumulation of the transported sediment on the reach bottom. The depth of sediment in the brooks varied between $0.3-1.1 \mathrm{~m}$. In general, the silted channel reaches were characterised by a flat bed and near-vertical channel banks, which were often undercut. Siltation of channels resulted in lower 
channel depth but unchanged channel width and sinuosity. Channel upper banks were covered with dense vegetation (Sp., grass), which efficiently protected the upper bank from erosion. Similar observations have been made in peatland streams [29] and in Wisconsin peatlands [30], where vegetation controlled the formation of channel hydraulic geometry. The median bed surface particle size showed an increase with unit stream power $\left(r^{2}=0.48, p\right.$ $=0.014$ ), when two data points were removed (Figure 3(d)); the organic bed of Mokinoja and the freshly silted Laukkupuro were not representative samples for this analysis, since organic sediment has different transportation characteristics than inorganic sediments [31]. An increase in the surface bed material with increasing stream power was expected, since larger unit stream power sort's bed sediment more efficiently. However, some scattering was noted, showing that local variations were high, depending mainly on variations in channel width.

In the brooks studied here, the abundant vegetation and low stream power characteristics have obviously led to the formation of channels with steep, well-vegetated banks, higher sinuosity and higher width-to-depth ratios. The width-to-depth ratio was on average 2.1 , with a range from 0.5 to 4.7 . The natural width-to-depth ratio (without the silted sediment) averaged 1.2, with a range from 0.4 to 2.0. The bankfull discharge and width-todepth ratio showed a weak correlation $\left(\mathrm{r}^{2}=0.25, \mathrm{p}=\right.$ 0.001 ), when the natural (not silted) depth was used. These measured values are in agreement with results reported for peatland channels [29], where a width-todepth ratio of $\sim 2$ was found to be typical. This confirms that the brook reaches in this study have naturally limited sediment transport capacity, and are therefore vulnerable to additional sediment inputs from land use.

Hydraulic geometry was not uniform between study reaches. Large variation was also observed within individual reaches. In natural rivers, channel width and depth usually increase downstream [12,32], with the width increasing faster than the depth [33,34]. In this study, there was a significant increase in downstream channel depth (without silted sediment) (Figure 3(b), $\mathrm{r}^{2}=0.37, \mathrm{p}=$ $0.009)$, but not in downstream channel width. The width increased faster than the depth $\left(r^{2}=0.29, p=0.001\right)$ but there was scattering due to site-specific factors such as channel and bank shape, and local vegetation (Figure 3(c)).

Channel width in particular varied markedly within individual reaches due to local factors such as bank shape, which also affected the relationship between catchment size and channel width. The results highlight the importance of local vegetation and bank shape in stabilising channel form in small brooks.

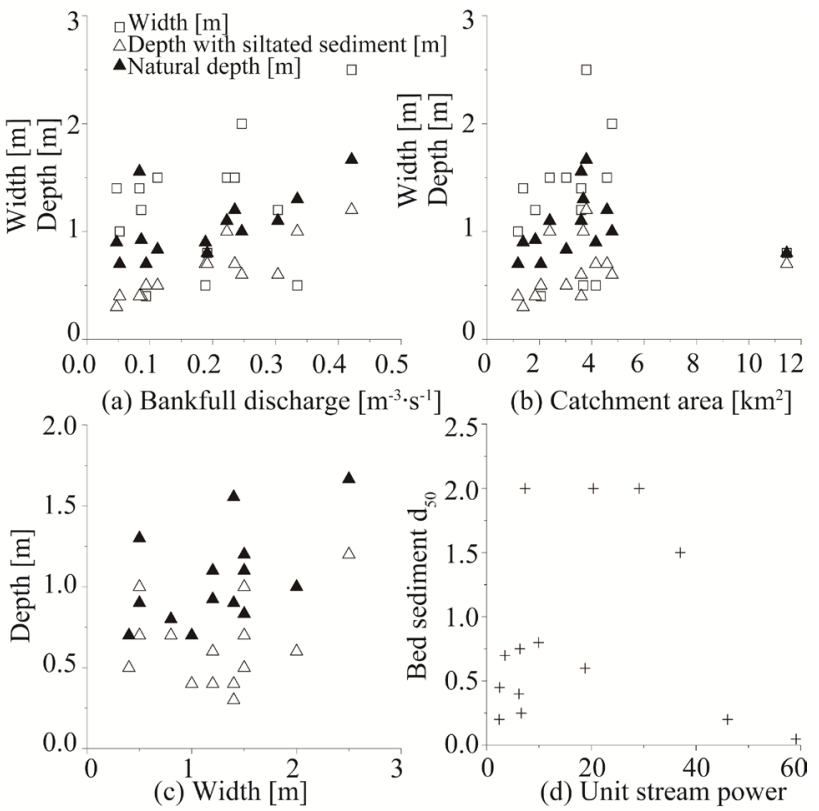

Figure 3. Comparison of channel features for all study reaches. The values shown are average values for each reach. Channel width and depth as a function of (a) bankfull discharge; (b) catchment area; (c) channel depth as a function of width; (d) median bed surface particle size as a function of unit stream power.

The theory of hydraulic geometry [12] was used to compare study brooks against common stream morphology theory and to examine whether common guidelines for brook morphology can be formulated. The only correlation observed was between bankfull discharge and channel bankfull depth $\left(\mathrm{r}^{2}=0.82, \mathrm{p}=0.01\right)$, with $\mathrm{r}^{2}=$ $0.31, \mathrm{p}=0.000$ when depth without silted sediment was used (Figure 3(a)). The coefficients in the hydraulic geometry equations were $\mathrm{c}=1.58$ and $\mathrm{f}=0.52$ for the silted bed depth and $\mathrm{c}=1.51$ and $\mathrm{f}=0.21$ for the natural depth. The values for the silted bed depth are close to values observed in cohesive soil reaches [35], whereas the natural depth values are close to boulder-bed rivers or pool-riffle sequences [33]. The relationship between discharge and velocity or width did not show any correlations, which further emphasises the importance of local characteristics for width and velocity variations. Small brooks seem to have large morphological diversity, which needs to be taken into consideration when restoring straightened reaches in small headwater areas. For example, the width should not be uniform in restored reaches.

\subsection{Channel Hydraulics}

The Vantunlamminoja site discharge during 2006 - 2008 fluctuated notably from 0.01 to $0.42 \mathrm{~m}^{3} \cdot \mathrm{s}^{-1}$. The ratio of mean annual discharge to bankfull discharge averaged 
0.1 at the Vantunlamminoja site. Local channel morphology and landscape strongly influenced the hydrographs and also bankfull occurrence. Bankfull discharge was reached or exceeded on average occasions 16 days per year, with a range from 14 to 18 days per year. The recurrence interval of bankfull discharge at Vantunlamminoja averaged $1.1 \mathrm{yr}$. Sediment sorting and trapping mainly occurs during bankfull conditions and is therefore limited to very few days during the year, limiting the recovery process from the additional sediment input. The unit stream power averaged 18.2, with a range from 2.4 to 59.1 (Table 1). The calculated or estimated Manning's $n$ values varied from 0.031 to 0.039 . These values are within the $0.03-0.07$ range reported for natural small streams [36-37]. The estimated $n$ values in the present study did not exceed 0.04 .

\subsection{Sediment Properties in Study Reaches}

The median bed sediment particle size at the study sites ranged from 0.2 to $2.0 \mathrm{~mm}$, organic material content from 10 to $95 \%$ and organic material particle size from 0.45 to $182 \mu \mathrm{m}$ (Table 1). The organic matter present in all sediment samples was in the form of forest litter, peat and humus. Comparisons of the calculated bankfull basal shear streass with the bed sediment critical shear stress revealed that at all sites, the bed sediment $\left(\mathrm{d}_{50}\right)$ was mobile during base flow conditions. The bed sediment was not armoured in most areas, and the subsurface particle sizes were equal to those of surface sediment. The ratio of median bed particle size to median subsurface particle size ranged from 1.0 to 2.2. Only at the Tunturioja and Nokipuro sites did particle size show signs of armouring, with upper layers being coarser than sublayers. The bed surface ratio was observed to increase with gradient $\left(\mathrm{r}^{2}=\right.$ $0.60, \mathrm{p}=0.000$ ). Bed sediment in smaller side-channels at Vantunlamminoja (Figure 1, not shown in Table 1) was mostly well-sorted and there was a distinct armour layer with average $d_{50} 4.1 \mathrm{~mm}$, while the ratio of bed to subsurface $\mathrm{d}_{50}$ averaged 5.8. Bankfull depth in these channels was only $0.15-0.2 \mathrm{~m}$, channel slope $0.03-0.04$ and water velocity $0.35-0.5 \mathrm{~m} \cdot \mathrm{s}^{-1}$ during average flow conditions. In headwater channels where armouring is present, the ratio can range from 1.8 to 5.0 [7]. Low armouring ratio and homogeneous bed material were expected, since the study areas were silted with eroded and transported sediment from the upstream catchment. It is noteworthy that even when erosion and transport of additional sediment from land use (forest drainage) ended, the bed surfaces were still poorly armoured. This indicates slow recovery from additional sediment input and agrees with observations of natural limited sediment transport capacity. Armouring has been linked to a sediment supply that is less than the ability of the stream to transport that load [38]. Although the bed sediment was not well armoured, sediment sorting according to erosion location and brook bed sediment was noted at all sites. In general, the silted brook reaches contained larger particle sizes than were observed at the sediment source, indicating flushing of particles finer than fine sand to the downstream reaches. The results indicate that slopes larger than 0.02 in forest brooks can transport the sediment delivered from upstream areas, even in small brook channels. In areas with slope $<0.02$, the sediment started to accumulate on the channel bottom. This is in accordance with previous findings, as $<0.02$ slope areas are normally classified as pools [39] or meandering reaches.

Flood plains and channel banks contained median particle sizes from 0.2 to $0.5 \mathrm{~mm}$. The sediment delivered to floodplains was found at a distance of 0.5 to $2 \mathrm{~m}$ from the channel, indicating that only minor areas of floodplains are involved in sediment trapping in headwater areas. Particles larger than fine sand were not found on floodplains, even though larger particles existed in bed sediment. Sediment on floodplains was often trapped in a thick peat moss layer (Sp.) and was found at a depth of 5 to $15 \mathrm{~cm}$ under the peat surface. However, peat layers were often full of sediment, indicating that peat has a limited capacity to trap transported sediment to floodplains. Peat moss may play a considerable role in sediment trapping and in determining the sediment budget of brooks in these areas.

The results indicate that the most heavily silted reaches with low slope, such as meandering sections, have the capability to sort and trap incoming sediment smaller than fine sand. The most problematic sediment for these reaches is coarse sand, as it is mainly transported as bedload and fills up the natural depth variations. Therefore, these sites should be given high priority in restoration planning. Even thought, results show clearly that bed sediment is capable to transport during bankfull conditions (basal shear stress exceeds sediments critical shear stress) at all study reaches, field observations demonstrate slow movement of this bed load fraction at brook beds. This reasoning is based on the supposition that meandering brooks channels with low gradient have limited sediment transport capacity and especially bed load move only infrequently. In this scenario, bed load is moved through the system slowly by low frequency, high magnitude events. This is demonstrated in reaches where effect of sediment input by drainage is still detectable over 20 years after the drainage operation. Nevertheless, holistic stream restoration should take issues at the catchment scale, before addressing reach scale problems $[40,41]$. In these areas, is means preventing additional sediment input from land use to the brooks.

No extensive data on bedload movement are available 
for these areas. However, the few measurements made during bankfull stage in the Vantunlamminoja area (reach 3) provided some information. The measured average median particle size $\left(\mathrm{d}_{50}\right)$ from all bedload samples was $0.45 \mathrm{~mm}$. This indicates that the majority of eroded material is transported in the bedload fraction (Table 1). Samples also contained small organic debris pieces of 1 $14 \mathrm{~mm}$ width and $11-50 \mathrm{~mm}$ length. Based on these measurements and knowledge of bankfull stages, the annual bedload yield during bankfull stages was calculated to be approx. $500 \mathrm{~kg} \cdot \mathrm{year}^{-1}$. In particular, at the Vantunlamminoja site the bed sediment was transported as large dunes, with the leading dune covering all existing depth variations. The average travel time for this foremost sand dyne was $2-3 \mathrm{~m} \cdot \mathrm{year}^{-1}$ and it contained approx. $2400 \mathrm{~kg} \cdot \mathrm{year}^{-1}$ of inorganic sediment, mainly coarse sand. The bedload was measured during high flow events, giving a good estimation of transport during these events.

Average suspended solids concentration (derived from turbidity and water sample measurements) at Vantunlamminoja was $3.2 \mathrm{mg} \cdot \mathrm{L}^{-1}$, with a range from 1.9 to $19.9 \mathrm{mg} \cdot \mathrm{L}^{-1}$. These values are higher than those reported in headwaters for pristine and old drainage conditions [5], $[42,43]$. In the present study the suspended solids mainly consisted of fine organic material (peat), which is typical for suspended sediment from drainage areas [3]. The suspended solids mainly consisted of organic material (peat), their main peaks followed discharge peaks at bankfull stage and hysteresis curves were clockwise, which indicates the importance of bankfull discharge for suspended sediment transport. Clockwise hysteresis indicates that settled organic material was easily transported during rising flow events. Settling of fine organic material to the surface of bed sediment during low flow conditions was observed in all four study reaches at Vantunlamminoja. This organic blanket often covered the entire channel bed surface and it may play a significant role in hyporheic transport processes. It has previously been noted that organic sediment affects salmon reproduction and the benthic community [44-46]. However, results show problem in Vantunlamminoja site in bed load, not suspended solids. This reflects especially to trout spawning success as sand blocks the gravel bed.

Analysis of the sediment samples in this study demonstrated that a large proportion of the bed material and particulate load transported by a brook can originate from peatland drainage areas where peat layers are weathered and eroded [5]. The particle sizes were similar to those measured previously in peat mining areas or forest drainage sites [5], [31]. Organic material in brook channels was entrained during bankfull conditions and was partly trapped on floodplains, where it undergoes oxidation and decomposition processes, affecting the reach sediment budget. Very little is known about these processes in boreal headwater areas, but they may play a significant role in total organic sediment load in a catchment.

\section{Conclusions}

Episodic erosion processes caused by forest drainage have led to extensive siltation of brook reaches in north-east Finland causing dramatic changes into brook bed substrates. The result from this study showed that peatland forest drainage had resulted in silted and non-armoured channel beds at many of the sites studied, resulting in lower channel depth but unchanged channel width and sinuosity.

The results indicate bed sediment in brooks is almost continuously mobile, which negatively reflect to ecological status of the brooks. The most heavily silted reaches with low slope, such as meandering sections, have the capability to transport through the reach or sort and trap incoming sediment smaller than fine sand to floodplains. The most problematic sediment for these reaches is coarse sand, as it is mainly transport in bedload and fills up the natural depth variations. Different reaches can be prioritised according to characteristics of the silted bed sediment or sediment from erosion locations. Sites silted with fine fractions need only minor restoration, whereas coarser fractions such as coarse sand require stronger restoration operations, e.g. mechanical dredging.

Hydraulic geometry studies confirms that the brook reaches in this study have naturally limited sediment transport capacity, and are therefore vulnerable to additional sediment inputs from land use. Results further emphasises the importance of local characteristics for width and velocity variations. Small brooks seem to have large morphological diversity, which needs to be taken into consideration when restoring straightened reaches in small headwater areas. For example, width should not be uniform in restored reaches. The morphology values and other channel geometry variations reported here can be useful when considering restoration actions for small brooks, especially those which are fully drained and straightened and have no neighbouring pristine channel sections to act as a model.

\section{Acknowledgements}

This work was carried out and partly funded by the forest brook restoration project led by the North Ostrobothnia Regional Environment Centre in Finland. The article was written with support from KIRSU graduate school (Academy of Finland), Tor and Maj Nessling foundation, 
MVTT, Thule-institute at University of Oulu, ModStream project by Academy of Finland and the Ministry of Agriculture and Forestry. The authors would like to thank all participants in the brook restoration project. Special thanks to Mr. Eero Moilanen, Mr. Eero Hartikainen, Mrs Pirkko-Liisa Luhta from Metsähallitus, Mrs Marita Ahola, Dr. Timo Yrjänä from the North Ostrobothnia Centre for Economic Development, Transport and the Environment and Mr Pekka Rossi from the University of Oulu.

\section{REFERENCES}

[1] J. L. Meyer and J. B. Wallace, "Lost Linkages and Lotic Ecology: Rediscovering Small Streams," In: M. C. Press, N. J. Huntly and S Levin, Eds., Ecology: Achievement and Challenge, Blackwell Scientific, Oxford, 2001, pp. 295-317.

[2] K. Virtanen, P. Hänninen, R.-L. Kallinen, S. Vartiainen, T. Herranen and R. Jokisaari, "Suomen Turvevarat 2000 (The Peat Reserves of Finland in 2000)," Geological Survey of Finland, Report of Investigation, Espoo, 2003, p. 156.

[3] H. Marttila and B. Kløve, "Dynamics of Suspended Sediment Transport and Erosion in a Drained Peatland Forestry Catchment," Journal of Hydrology, Vol. 388, No. 34, 2010, pp. 414-425. doi:10.1016/j.jhydrol.2010.05.026

[4] S. Joensuu, "Effects of Ditch Network Maintenance and Sedimentation Ponds on Export Loads of Suspended Solids and Nutrients from Peatland Forests," Finnish Forest Research Institute, Research Papers 868, 2002.

[5] T. Mattsson, L. Finér, P. Kortelainen and T. Sallantaus, "Brook Water Quality and Background Leaching from Unmanaged Forested Catchments in Finland," Water, Air, and Soil Pollution, Vol. 147, No. 1-4, 2003, pp. 275-297. doi:10.1023/A:1024525328220

[6] F. J. Triska, V. C. Kennedy, R. J. Avanzino, G. W. Zellweger and K. E. Bencala, "Retention and Transport of Nutrients in a Third-Order Stream in Northwestern California: Hyporheic Processes," Ecology, Vol. 70, No. 6, 1989, pp. 1893-1905. doi:10.2307/1938120

[7] P. J. Whiting, J. F. Stamm, D. B. Moog and R. L. Orndorff, "Sediment-Transporting Flows in Headwater Streams," Geological Society of America Bulletin, Vol. 111, No. 3, 1999, pp. 450-466.

doi:10.1130/0016-7606(1999)111<0450:STFIHS $>2.3 . C O ; 2$

[8] S. M. Wondzell and F. J. Swanson, "Floods, Channel Change, and the Hyporheic Zone," Water Resources Research, Vol. 35, No. 2, 1999, pp. 555-567. doi:10.1029/1998WR900047

[9] T. Dogwiler and C. M. Wicks, "Sediment Entrainment and Transport in Fluviokarst Systems," Journal of Hydrology, Vol. 295, No. 1-4, 2004, pp. 163-172. doi:10.1016/j.jhydrol.2004.03.002

[10] E. W. Peterson, T. B. Sickbert and S. L. Moore, "High
Frequency Stream Bed Mobility of a Low-Gradient Agricultural Stream with Implications on the Hyporheic Zone," Hydrological Processes, Vol. 22, No. 21, 2008, pp. 4239-4248. doi:10.1002/hyp.7031

[11] A. St-Hilaire, D. Caissie, R. A. Cunjak and G. Bourgeois, "Streambed Sediment Composition and Deposition in a Forested Stream: Spatial and Temporal Analysis," River Research and Applications, Vol. 21, No. 8, 2005, pp. 883-898. doi:10.1002/rra.860

[12] L. B. Leopold and T. Maddock Jr., "The Hydraulic Geometry of Stream Channels and Some Physiographic Implications," US Geological Survey Professional Paper 252, 1953.

[13] R. R. De Rose, M. J. Stewardson and C. Harman, "Downstream Hydraulic Geometry of Rivers in Victoria, Australia," Geomorphology, Vol. 99, No. 1-4, 2008, pp. 302- 316. doi:10.1016/j.geomorph.2007.11.008

[14] G.S. Ridenour, "Compositional Data Analysis of the Influence of Drainage Area and Stream Order on Hydraulic Geometry," Proceedings of the IV International Conference on GeoComputation, Fredericksburg, 25-28 July 1999.

[15] S. Hyvönen, M. Suanto, P.-L. Luhta, T. Yrjänä and E. Moilanen, "Stream Inventories in the River Ii-joki Catchment Area during 1998-2003 (Regional Environmental Publications)," Tornion Kirjapaino, 2005.

[16] L. B. Leopold, “A View of the River,” Harvard University Press, Cambridge, 1994.

[17] EPA, "Sediment Sampling Quality Assurance User's Guide," Environmental Monitoring System Laboratory, Las Vegas, 1985.

[18] D. A. Braatz and T. L. Randall, "A New Series of Sediment Collectors for Developing Bed Load Sediment Budgets and Restoring Streams," International Symposium on Sediment Budgets, Foz do Iguaço, No. 291, 2005, pp. 222-226.

[19] V. T. Chow, “Open-Channel Hydraulics," McGraw-Hill Book Co., New York, 1959.

[20] G. J. Arcement and V. R. Schneider, "Guide for Selecting Manning's Roughness Coefficients for Natural Channels and Floodplains," US Geological Survey Water Supply Paper 2339, 1989.

[21] M. S. Lorang and F. R. Hauer, "Flow Competence and Streambed Stability: An Evaluation of Technique and Application," Journal of North American Benthological Society, Vol. 22, No. 4, 2003, pp. 475-491. doi: $10.2307 / 1468347$

[22] V.R. Baker and D.F. Ritter, "Competence of Rivers to Transport Coarse Bedload Material," Geological Society of America Bulletin, Vol. 86, No. 7, 1975, pp. 975-978. doi:10.1130/0016-7606(1975)86<975:CORTTC $>2.0 . C O ; 2$

[23] S.L. Dingman, "Fluvial Hydrology", W. H. Freeman and Company, New York, 1984.

[24] W. H. Graf, "Hydraulics of Sediment Transport," Water Resources Publications, LLC., Colorado, 1984.

[25] C. F. Rabeni and G. W. Minshall, "Factors Affecting 
Microdistribution of Stream Benthic Insects," Oikos, Vol. 29, No. 1, 1977, pp. 33-43. doi:10.2307/3543290

[26] G. Parker and P. C. Klingeman, "On Why Gravel Bed Streams Are Paved," Water Resources Research, Vol. 18, No. 5, 1982, pp. 1409-1423. doi:10.1029/WR018i005p01409

[27] Y. Nino, F. Lopez and M. Garcia, "Threshold for Particle Entrainment into Suspension," Sedimentology, Vol. 50, No. 2, 2003, pp. 247-263. doi:10.1046/j.1365-3091.2003.00551.x

[28] R. A. Bagnold, "Bed Load Transport by Natural Rivers," Water Resources Research, Vol. 13, No. 2, 1977, pp. 303312. doi:10.1029/WR013i002p00303

[29] R. A. Nanson, G. C. Nanson and H. Q. Huang, "The Hydraulic Geometry of Narrow and Deep Channels; Evidence for Flow Optimisation and Controlled Peatland Growth," Geomorphology, Vol. 117, No. 1-2, 2010, pp. 143-154. doi:10.1016/j.geomorph.2009.11.021

[30] J. R. Watters and E. H. Stanley, "Stream Channels in Peatlands: The Role of Biological Processes in Controlling Channel Form," Geomorphology, Vol. 89, No. 1-2, 2007, pp. 97-110. doi:10.1016/j.geomorph.2006.07.015

[31] H. Marttila and B. Kløve, "Erosion and Delivery of Deposited Peat Sediment," Water Resources Research, Vol. 44, 2008, W06406, 10 p. doi:10.1029/2007WR006486

[32] D. Knighton, "Fluvial Forms and Processes: A New Perspective," Arnold, London, 1998.

[33] J. C. Bathurst, "Flow Resistance through the Channel Network," In: K. Beven and M. J. Kirkby, Eds., Channel Network Hydrology, John Wiley \& Sons, Chichester, 1993, pp. 69-98.

[34] A. W. Western, B. L. Finlayson, T. A. McMahon and I. C. O'Neill, "A Method for Characterising Longitudinal Irregularity in River Channels," Geomorphology, Vol. 21, No. 1, 1997, pp. 39-51. doi:10.1016/S0169-555X(97)00023-8

[35] T. Helmiö, "Hydraulic Geometry of Cohesive Lowland Rivers," Boreal Environment Research, Vol. 9, 2004, pp. 243-251.

[36] M. Kuuskoski, "Hydrauliikka," In: S. Mustonen, Ed., Suo
menRaken nusinsi nööriliiton julkaisusarja 67., Maaja vesirakennus, Vammalan kirjapaino, 1968.

[37] L. Hosia, "Pienten Uomien Virtausvastuskerroin," National Board of Waters, Finland, Report 199, Helsinki, 1980.

[38] W. E. Dietrich, J. W. Kirchner, H. Ikeda and F. Iseya, "Sediment Supply and the Development of the Coarse Surface Layers in Gravel-Bed Rivers," Nature, Vol. 340, 1989, pp. 215-217. doi: 10.1038/340215a0

[39] M. Church, "Geomorphic Thresholds in Riverine Landscapes," Freshwater Biology, Vol. 47, No. 4, 2002, pp. 541-557. doi:10.1046/j.1365-2427.2002.00919.x

[40] D. A. Sear, "River Restoration and Geomorphology," Aquatic Conservation: Marine and Freshwater Ecosystems, Vol. 4, No. 2, 1994, pp.169-177.

[41] D. A. Sear, M. D. Newson, C. Hill, J. Old and J. Branson, "A Method for Applying Fluvial Geomorphology in Support of Catchment-Scale River Restoration Planning," Aquatic Conservation: Marine and Freshwater Ecosystems, Vol. 19, No. 5, 2009, pp. 506-519. doi:10.1002/aqc. 1022

[42] M. Ahtiainen and P. Huttunen, "Long-Term Effects of Forestry Managements on Water Quality and Loading in Brooks," Boreal Environment Research, Vol. 4, 1999, pp. 101-114.

[43] S. Joensuu, E. Ahti and M. Vuollekoski, "Discharge Water Quality from Old Ditch Networks in Finnish Peatland Forests," Suo-Mires, Vol. 52, No. 1, 2001, pp. 1-15.

[44] M. Rask, K. Nyberg, S.-L. Markkanen and A. Ojala, "Forestry in Catchments: Effects on Water Quality, Plankton, Zoobenthos and Fish in Small Lakes," Boreal Environment Research, Vol. 3, 1998, pp. 75-86.

[45] A. Laine and K. Heikkinen, "Peat Mining Increasing Fine-Grained Organic Matter on the Riffle Beds of Boreal Streams," Archiv fur Hydrobiologie, Vol. 148, No. 1, 2000, pp. 9-24.

[46] A. Laine, "Effects of Peatland Drainage on the Size and Diet of Yearling Salmon in a Humic Northern River," Archiv für Hydrobiologie, Vol. 151, 2001, pp. 83-99. 